\title{
Asthma, inhaled corticosteroid treatment, and growth
}

Titus K Ninan, George Russell

\begin{abstract}
To evaluate the effects on growth of inhaled corticosteroid treatment (ICT) and of the quality of control of asthma, height velocity was studied in $\mathbf{5 8}$ prepubertal children attending a specialist asthma clinic because of chronic asthma that was difficult to control. The height velocity standard deviation (SD) score was maximal when the asthma was well controlled both before $(0.01)$ and after $(-0.07)$ starting ICT. It was least when the asthma was poorly controlled both before $(-1 \cdot 50)$ and after (-1.55) starting ICT. The effectiveness of control correlated significantly with the height velocity SD score, both before and after ICT was started. No evidence was found that the administration of ICT has an adverse effect on growth.
\end{abstract}

Inhaled corticosteroid treatment (ICT) has been used to treat moderate to severe asthma since the early 1970s, ${ }^{12}$ the two drugs most commonly used in the UK are beclomethasone dipropionate and budesonide. Occasional minor side effects such as oral thrush, dysphonia, and hoarseness have been reported. ${ }^{13}$ Adrenal suppression has been observed in patients on ICT, but the dose at which this occurs varies. Some investigators have noted evidence of adrenal suppression in patients on conventional doses of ICT ${ }^{45}$ while others have found adrenal dysfunction only with higher than conventionally recommended doses. ${ }^{16}$

Growth retardation in severe childhood asthma was described long before the introduction of $\mathrm{ICT}^{7-9}$; it also occurs as a complication of long term systemic corticosteroid treatment for asthma. ${ }^{10} 11$ The effect of ICT on linear growth, is however, controversial. ${ }^{1-3}$ 12-14

This study evaluated the effects of ICT and the severity of asthma on linear growth in prepubertal children with severe chronic bronchial asthma, many of whom were poorly controlled despite higher than conventionally recommended doses of ICT.

\section{Patients and methods}

The growth of 58 children ( 38 boys and 20 girls) with chronic asthma was followed up for a mean duration of 4.9 years (range 2.6-9.4 years).

The children studied were suffering from recurrent or chronic asthma, which was sufficiently severe to require regular hospital review that included assessment of their growth. Height was measured on the same stadiometer by a small group of nurses who were also responsible for measuring children attending the local growth centre, thus ensuring a standardised technique. Asthma control was assessed by a symptom score based on the frequency, duration, and severity of wheezing and on the number of days per week on which rescue medication (systemic steroids or bronchodilator treatment) was used (table 1). For each category a score of $0-4$ was given to produce a maximum of 16 points. A score of 5 or less was classed as good control, 6-10 as moderate control, and greater than 10 as poor control. Each of these children were followed up for a minimum of one year when not receiving ICT and for at least another year when on a continuous ICT.

To avoid pubertal influences, growth was studied in boys until the 11th birthday and in girls up to the 10th birthday. The mean age of entry into the study was 3.5 years for boys and 4.4 years for girls. The mean age of exit from the study was 9 years for boys and $7 \cdot 5$ years for girls.

Each child was treated initially with $\beta_{2}$ receptor stimulants, theophylline, and/or sodium cromoglycate for a mean duration of 1.8 years (range $1-6.5$ years). Because of inadequate control of interval symptoms the children were then started on ICT (budesonide or beclomethasone dipropionate). The selection of drug was based on the type of inhalation device which the patient was best able to use: budesonide was generally given by a large spacer (Nebuhaler, Astra) whereas beclomethasone dipropionate was generally given by metered dose inhaler or dry powder inhaler (Rotahaler, Allen and Hanburys).
Department of Child

of Aberdeen

Titus $\mathrm{K}$ Ninan

George Russell

Correspondence to: Dr Titus K Ninan, Department of Child Health, Polwarth Building, Foresterhill,

Aberdeen AB9 2ZD.

Reprints available from Dr George Russell Department of Medica Paediatrics,

Royal Aberdeen Children's Hospital, Cornhill Road, Aberdeen ABI 8NB.

Accepted 10 February 1992
Table 1 Asthma symptom score

\begin{tabular}{|c|c|c|c|c|}
\hline & \multicolumn{4}{|l|}{ Score } \\
\hline & $l$ & 2 & 3 & 4 \\
\hline $\begin{array}{l}\text { Frequency of wheeeing in the } \\
\text { past } 2 \text { months (days) }\end{array}$ & $0-3$ & 47 & $8-14$ & $>14$ \\
\hline $\begin{array}{l}\text { Typical duration of episodes (hours) } \\
\text { Type of treatment required }\end{array}$ & $\begin{array}{l}<1 \\
\text { Inhaled } \\
\quad(<4 \text { puffs/day })\end{array}$ & $\begin{array}{l}\stackrel{1-6}{\text { Inhaled }} \\
(\geqslant 4 \text { puffs/day })\end{array}$ & $\begin{array}{l}7-24 \\
\text { Nebuliser }\end{array}$ & $\begin{array}{l}>24 \\
\text { Hospital admission }\end{array}$ \\
\hline $\begin{array}{l}\text { Rescue medication in the } \\
\text { past } 2 \text { months (days) }\end{array}$ & $<4$ & 47 & $8-14$ & $>14$ \\
\hline
\end{tabular}


To achieve rapid control of the asthma ICT was usually started at a dose of $400 \mu \mathrm{g}$ per day that was then adjusted (usually downwards) at regular intervals depending on the response to treatment. In most patients satisfactory control was attained rapidly on ICT given in a dose of $400 \mu \mathrm{g}$ or less per day, and the patient was discharged from further review. The patients in the present study are those in whom satisfactory control of symptoms was harder to achieve, who commonly required higher doses of ICT, and who therefore required long term review. In the patients studied the median dose of ICT was $800 \mu \mathrm{g}$ (range 200-1600 $\mu \mathrm{g}$ ); treatment with sodium cromoglycate was suspended once ICT was commenced. The children were then followed up for a mean duration of $2 \cdot 7$ years (range $1-5 \cdot 1$ years).

Height velocity was calculated and expressed as height velocity standard deviation (SD) scores according to age using the formula:

Height velocity Height velocity-mean height velocity for age SD score $=\frac{\text { SD of height velocity for age }}{\text { a }}$

After calculating the height velocity SD score the values were centralised on the point at which ICT was commenced and, because of the non-normal distribution of the values, geometric means were calculated for each patient before and after starting ICT. Analysis of variance was used to evaluate the effect on growth of sex and asthma control before and after the administration of ICT. Correlation coefficients were used to evaluate the relationships between asthma control, sex, and height velocity SD score before and after starting ICT.

\section{Results}

The 58 children had a mean height velocity throughout the period of observation of -0.54 (range $-4 \cdot 20$ to $+2 \cdot 90$ ). The rate of growth for girls was less than that of the boys though the difference between the means was not statistically significant (table 2). From tables 3 and 4 it is apparent that subjects whose asthma was well controlled grew well whereas those subjects whose asthma was badly controlled grew poorly,

Table 2 Mean height velocity $S D$ score of the 58 children studied. Results are mean $(S E)^{*}$

\begin{tabular}{lll}
\hline & Before ICT & After ICT \\
\hline Boys $(n=38)$ & $-0.42(0.19)$ & $-0.53(0 \cdot 19)$ \\
Girls $(n=20)$ & $-0.76(0.22)$ & $-0.70(0.24)$ \\
All $(n=58)$ & $-0.51(0.14)$ & $-0.59(0 \cdot 14)$
\end{tabular}

*There was no significant difference between the means before and after ICT.

Table 3 Effect of asthma control on height velocity $S D$ score before ICT was started

\begin{tabular}{lrl}
\hline Control & Mean $(S E)$ & $\begin{array}{l}\text { 95\% Confidence } \\
\text { interval }\end{array}$ \\
\hline Good & $0.01(0.14)$ & -0.27 to 0.30 \\
Moderate & $-0.83(0.23)$ & -1.33 to -0.34 \\
Poor & $-1.50(0.39)$ & -2.37 to -0.62
\end{tabular}

Significance of difference between means: good $v$ poor, $t=3 \cdot 64$, $\mathrm{p}=0.003$; good $v$ moderate, $t=3.11, \mathrm{p}=0.004$; and moderate $v$ poor, $t=1 \cdot 45$, NS
Table 4 Effect of asthma control on height velocity $S D$ score after ICT was started

\begin{tabular}{lll}
\hline Control & Mean $(S E)$ & $\begin{array}{l}\text { 95\% Confidence } \\
\text { interval }\end{array}$ \\
\hline Good & $-0.07(0.24)$ & -0.60 to 0.45 \\
Moderate & $-0.49(0.17)$ & -0.85 to -0.13 \\
Poor & $-1.55(0.31)$ & -2.25 to -0.85 \\
\hline
\end{tabular}

Significance of difference between means: good $v$ poor, $t=2 \cdot 92$, $\mathrm{p}=0.009$; good $v$ moderate, $t=1.39$, NS; and moderate $v$ poor $t=3 \cdot 67, \mathrm{p}=0 \cdot 001$.

Table 5 Correlation coefficients between sex, ICT dose, asthma control, and height velocity SD score before and after starting ICT

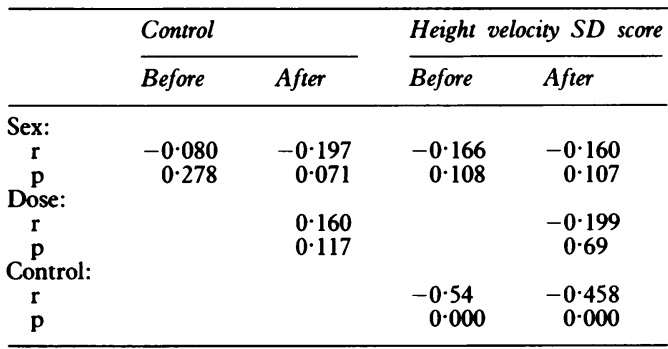

regardless of whether or not they were receiving ICT. Height velocity SD score correlated negatively with control of asthma both before and after commencing ICT (table 5) but not with the dosage of ICT used.

The height velocities of the 16 children on whom we had growth data for more than two years both before and after starting ICT were considered separately on a year by year basis; there was no change in height velocity after starting ICT.

\section{Discussion}

The use of inhaled steroids is firmly established as one of the mainstays in the maintenance treatment of children with moderate and severe asthma. ${ }^{1-3}$ The currently accepted indication for long term use of ICT is the presence of chronic asthma that is not adequately controlled by non-steroidal drugs. In most children adequate control of asthma can be obtained with doses between 100 and $600 \mu \mathrm{g}$ per day. ${ }^{15}$ The therapeutic effects of ICT are, however, dose dependent ${ }^{16}$ and it may occasionally become necessary, as in the majority of children in this study, to increase the dosage to achieve optimum control of the asthma.

Although Littlewood et al concluded that ICT produced growth impairment in asthmatic children, ${ }^{13}$ many of their patients were of an age when pubertal changes would be expected to be influencing growth. Balfour-Lynn has shown that asthma is associated with a relative deceleration of growth in later childhood leading to delayed puberty. ${ }^{12}$ In our study pubertal influences were avoided by studying boys only until the 1lth birthday and girls until the 10th birthday. Objective measurements on the pubertal status of the children were not made, though the ages at exit (mean 9 years for boys and $7 \cdot 5$ years for girls) would make it unlikely that pubertal changes played a significant part.

The 58 children in this study, whose asthma 
was frequently poorly controlled, tended to show relative growth impairment both before and after they were commenced on ICT, a previously observed phenomenon. ${ }^{17}$

Of the possible influences on growth that we studied, the only factor with a significant effect was the quality of control of the asthma. The linear growth of children with poorly controlled asthma was significantly slower than in those whose asthma was well controlled, a finding which was observed both before and after starting ICT (tables 3 and 4). The dose of ICT did not correlate with height velocity SD score (table 5) and although girls showed slightly more growth impairment than boys, the difference was not significant.

In this study it was apparent that whereas the control of the asthma had a major effect on growth, ICT had no such effect. This finding is in keeping with the observation long before ICT was introduced that childhood asthma is associated with growth impairment, ${ }^{7-9}$ a finding which has been related to both the severity of the asthma ${ }^{18}$ and to the existence of the atopic state. $^{17}$

We have therefore been unable to demonstrate any adverse effect of ICT on growth; when growth impairment occurs in an asthmatic child this is more likely to reflect poor asthma control than the administration of ICT.

We thank Daphne Russell for helpful statistical advice and Dr Peter Smail for advice on the calculation of height velocity SD scores.
1 Kerrabijn KF. Beclomethasone dipropionate in long-term treatment of asthma in children. $\mathcal{F}$ Pediatr 1976;89:821-6. 2 Godfrey S, Konig P. Treatment of childhood asthma for thirteen months and longer with beclomethasone dipropionate aerosol. Arch Dis Child 1974;49:591-6.

3 Francis RS. Long-term beclomethasone dipropionate aerosol therapy in juvenile asthma. Thorax 1976;31:309-14.

4 Nassif E, Weinberger M, Sherman P, Brown K. Extrapulmonary effects on maintenance corticosteroid therapy with alternate-day prednisolone and inhaled beclomethasone in children with chronic asthma. $\mathcal{F}$ Allergy Clin Immunol 1987;80:518-29.

5 Law CM, Marchant JL, Honour JW, Preece MA, Warner JO. Nocturnal adrenal suppression in asthmatic children on inhaled beclomethasone dipropionate. Lancet 1986;i:942-4.

6 Prahl P, Jensen T, Bjerregard-Andersen H. Adrenocortical function in children on high-dose steroid aerosol therapy. function in children on

7 Cohen MB, Wella RR, Cohen S. Anthropometry in children. Progress in allergic children as shown by increments in height, weight and maturity. Am $\mathcal{F}$ Dis Child 1940;60: 1058-66.

8 Cohen MB, Abram LE. Growth patterns of allergic children. fournal of Allergy 1948;19:165-71.

9 Dawson B, Horobin G, Illsley R, Mitchell RG. A survey of childhood asthma in Aberdeen. Lancet 1969;i:827-30.

10 Falliers CJ, Tan LS, Szentivanyi J, Jorgensen JR, Bukantz SC. Childhood asthma and steroid therapy as influences on growth. Am $\mathcal{F}$ Dis Child 1963;105:127-37.

11 Spock A. Growth pattern in 200 children with bronchial asthma. Ann Allergy 1965;23:608-15.

12 Balfour-Lynn L. Growth and childhood asthma. Arch Dis Child 1986;61:1049-55.

13 Littlewood JM, Johnson AW, Edwards PA, Littlewood AE. Growth retardation in asthmatic children treated with inhaled beclomethasone dipropionate. Lancet 1988;i:115-6.

14 Graff-Lonnevig V, Kraepelin S. Long-term treatment with beclomethasone dipropionate aerosol in children with special reference on growth. Allergy 1979;34:57-61.

15 Togood JH, Lefcoe MN, Haines DSM, et al. Minimum dose requirements of steroid-dependent asthmatic patients for aerosol beclomethasone and oral prednisone. $\mathcal{F}$ Allergy Clin Immunol 1978;61:355-64.

16 Smith MJ, Hodson ME. High-dose beclomethasone inhaler in the treatment of asthma. Lancet 1983;i:265-9.

17 Ferguson AC, Murray AB, Tze W-J. Short stature and delayed skeletal maturation in children with allergic disease. F Allergy Clin Immunol 1982;69:461-6.

18 Hauspie R, Susanne C, Alexander F. Maturational delay and temporal growth retardation in asthmatic boys. $\mathcal{f}$ Allergy Clin Immunol 1977;59:200-6. 